\title{
CALCULATED HEAT FLOW FOR THE ENSENADA REGION, BAJA CALIFORNIA, MEXICO
}

\section{FLUJO DE CALOR CALCULADO PARA LA REGIÓN DE ENSENADA, BAJA CALIFORNIA, MÉXICO}

\author{
José María Beltrán-Abaunza* \\ Ana Luz Quintanilla-Montoya \\ Universidad Autónoma de Baja California \\ Instituto de Investigaciones Oceanológicas \\ Ensenada, Baja California, México \\ * E-mail: jbeltran3@go.com \\ Recibido en agosto de 2001; aceptado en octubre
}

\begin{abstract}
Due to the scarcity of heat flow data in the region of Ensenada, Baja California (Mexico), the present study calculated them using the silica geothermometer technique. The average heat flow value determined was $123.33 \pm 35.57 \mathrm{~mW} \mathrm{~m}^{-2}(2.95 \pm 0.85 \mathrm{HFU})$. Four zones within the study area, related to the main fault systems of the region, were found to have high hydrothermal activity. The potential use of geothermal resources in the area is feasible as it is considered a low geothermal system with water temperature values, above the static water level, that vary from $30^{\circ} \mathrm{C}$ to $108^{\circ} \mathrm{C}$.
\end{abstract}

Key words: heat flow, geothermometry, geothermal resource, Baja California, Mexico.

\section{RESUMEN}

Dada la escasez de datos de flujo de calor en la región de Ensenada, Baja California (México), éstos fueron calculados en el presente estudio utilizando la técnica de geotermometría de sílice. El valor medio de flujo de calor determinado fue de $123.33 \pm 35.57 \mathrm{~mW} \mathrm{~m}^{-2}(2.95 \pm 0.85 \mathrm{HFU})$. En el área de estudio se encontró que cuatro zonas, relacionadas con los principales sistemas de fallas de la región, poseen una alta actividad hidrotermal. El uso potencial de los recursos geotérmicos del área es factible ya que se considera un sistema geotermal bajo con valores de temperatura del agua, por arriba del nivel estático, que varían de $30^{\circ} \mathrm{C}$ a $108^{\circ} \mathrm{C}$.

Palabras clave: flujo de calor, geotermometría, recurso geotérmico, Baja California, México.

\section{INTRODUCTION}

The continental borderland of southern California (USA) and northern Baja California

\section{INTRODUCCIÓN}

La zona fronteriza continental del sur de California (USA) y el norte de Baja California 
(Mexico) are a geologically complicated part of the broad tectonic boundary between the North America and Pacific plates. Both of these areas constitute a common tectonic region that is affected by several active faults in a regional pattern, all of which belong to the San Andreas-Gulf of California system. Smith et al. (1979) and García-Estrada (1989) observed that in the western region of North America, the heat flow provinces are associated with the physiographical provinces, since both are the result of Cenozoic tectonic events, such as the subduction of the Farrallon plate, and the opening of the Gulf of California. This great tectonic activity originated the Baja California Peninsula (Atwater, 1970; Gastil et al., 1975) and the subduction process which gave as result the paleotransform fault known as Agua Blanca (Gastil et al., 1979). Agua Blanca is considered to be an active fault and the main system of the Ensenada region, located in the NW coast of Baja California (fig. 1). Not only it determines the whole physiography in the area of Punta Banda, the Maneadero Valley and the Todos Santos Islands but it also belongs to the tectonic province of Agua Blanca-San Miguel, where most of the active springs in the area have been reported (Gastil et al., 1981; Quintanilla-Montoya and Suárez-Vidal, 1992).

The reconnaissance geology of the Ensenada region has been summarized and described by Gastil et al. (1975). Three rock groups, denominated pre-batholitic, batholitic and post-batholitic, constitute the main lithologic assemblages. The pre-batholitic group is made up of Lower Cretaceous (Albian) marine sedimentary formations and of metamorphic rocks typical of eugeosynclinal deposits. The batholitic group is composed of crystalline plutonic rocks of the tonalite, gabbro and granodiorite type (Larsen, 1948, in Vidal et al., 1982). The post-batholitic group is made up of Upper Cretaceous (Maestrichtian) marine sedimentary formations, marine Pliocene
(México), son regiones geológicamente complicadas de la amplia frontera tectónica entre la placa de Norte America y la del Pacífico. Ambas constituyen una región tectónica común afectada por varias fallas activas regionalmente las cuáles, juntas, forman parte del sistema San Andrés-Golfo de California. Smith et al. (1979) y García-Estrada (1989), observaron que en la región occidental de Norteamérica las provincias de flujo de calor están asociadas con las provincias fisiográficas, ya que ambas son resultado de eventos tectónicos del Cenozoico, como la subducción de la placa Farallón y la apertura del Golfo de California. Esta gran actividad tectónica dió origen a la Península de Baja California (Atwater, 1970; Gastil et al., 1975) y al proceso de subducción que dió como resultado la falla paleotransforme conocida como Agua Blanca (Gastil et al., 1979). Agua Blanca es considerada como una falla activa y es el sistema principal de la región de Ensenada, localizada en la costa noroccidental de Baja California (fig. 1). Agua Blanca no solamente determina toda la fisiografía del área de Punta Banda, el valle de Maneadero y las Islas de Todos Santos, sino que también pertenece a la provincia tectónica de Agua Blanca-San Miguel, donde se han reportado la mayoría de los afloramientos activos de la zona (Gastil et al., 1981; Quintanilla-Montoya y Suárez-Vidal, 1992).

El reconocimiento geológico de la región de Ensenada ha sido sintetizado y descrito por Gastil et al. (1975). Los tres grupos de rocas denominados pre-batolítico, batolítico y postbatolítico, constituyen los principales conjuntos litológicos. El grupo pre-batolítico está constituido por formaciones sedimentarias marinas que datan del Cretácico temprano (Albiano) y por rocas metamórficas típicas de depósitos eugeosinclinales. El grupo batolítico está compuesto por rocas plutónicas cristalinas de tipo tonalita, gabro y granodiorita (Larsen, 1948, en Vidal et al., 1982). El grupo 


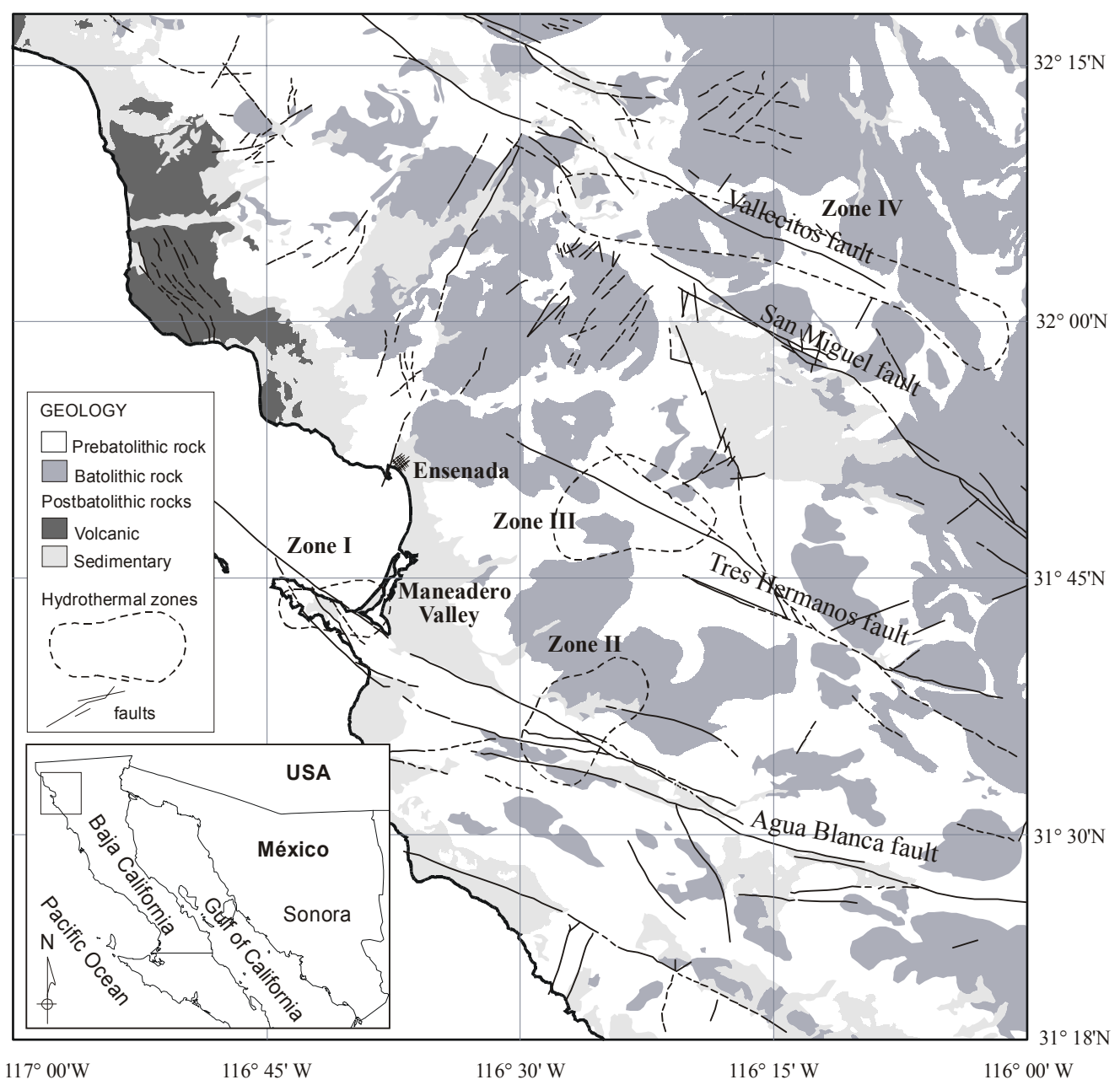

Figure 1. Study area.

Figura 1. Área de estudio.

deposits, Miocene basalt, volcanic andesites, and nonmarine sediments of Quaternary alluvium (Quintanilla-Montoya and Suárez-Vidal, 1992; Vidal et al., 1982).

Due to the regional tectonic pattern, Baja California has several hydrothermal springs that are important because of their potential use as sources for geothermal energy. Despite the fact that the Ensenada region has hydrothermal postbatolítico está constituido por formaciones sedimentarias marinas del Cretácico superior (Maestrichtiano), depósitos marinos del Plioceno, basaltos del Mioceno, andesitas volcánicas y sedimentos no marinos de aluvión cuaternario (Quintanilla-Montoya y SuárezVidal, 1992; Vidal et al., 1982).

Debido al patrón tectónico regional, Baja California tiene varios afloramientos 
activity, conventional estimates of the heat flow in the area, by means of direct measurements of temperature in depth, and thermal conductivity of rocks, have not been carried out. It is well known that indirect estimates are never as precise as direct temperature measurements, but according to Buntebarth (1994), if direct measurements lack for a place, indirect measurements can be used and, consequently, the silica geothermometer technique has been employed successfully. This technique has proved to be one of the most accepted ones worldwide, especially in developing countries, where economical constraints do not allow carrying out studies that include well boring to measure heat flow in situ. An example for this, is the Venezuelan heat flow data base, which is mainly based on measurements calculated from geochemical methods (Hamza and Muñóz, 1996).

The aim of the present study is to estimate heat flow values for the hydrothermal springs located in the Ensenada, Baja California, region and calculate a regional value of the heat flow in the zone as requested by the Comision Federal de Electricidad (the Mexican Federal Commission of Electricity) in order to continue with the explorations in the area.

\section{METHODOLOGY}

This study is based on the compilation of chemical analyses as well as on spring-waters data obtained from several sources (Álvarez, 1993; Gastil and Bertine, 1981; Secretaría de Programación y Presupuesto, 1981; Vidal et al., 1978; James, 1972).

Water temperature data for 62 wells were obtained, but only 45 had the required information to use a ternary diagram of $\mathrm{Cl}-$ $\left(\mathrm{HCO}_{3}+\mathrm{CO}_{3}\right)-\mathrm{SO}_{4}$, as proposed by Nicholson (1993) to classify the type of water of the hydrothermal springs, based on the dominant hidrotermales importantes debido a su potencial uso como fuentes de energía geotérmica. A pesar de que la región de Ensenada presenta actividad hidrotermal, no se han realizado cálculos convencionales de flujo de calor en el área mediante mediciones directas de temperatura a profundidad y conductividad térmica de las rocas. Es sabido que las estimaciones indirectas nunca son tan precisas como las mediciones directas de temperatura pero, de acuerdo a Buntebarth (1994), si en un lugar no existen mediciones directas, puede considerarse el uso de mediciones indirectas, por lo que la técnica de geotermometría de sílice ha sido utilizada con éxito. Esta técnica ha probado ser una de las más aceptadas a nivel mundial, especialmente en países en vías de desarrollo, en donde las limitaciones económicas no permiten llevar a cabo estudios que incluyan perforaciones para medir el flujo de calor in situ. Un ejemplo de ello es la base de datos de flujo de calor de Venezuela, basada principalmente en mediciones calculadas a partir de métodos geoquímicos (Hamza y Muñoz, 1996).

El objetivo del presente estudio es el de estimar valores de flujo de calor de los afloramientos hidrotermales localizados en la región de Ensenada, Baja California, y calcular un valor regional de flujo de calor para la zona, como ha sido requerido por la Comisión Federal de Electricidad para continuar con las exploraciones en el área.

\section{METODOLOGÍA}

Este estudio está basado en la compilación de análisis químicos así como en datos de aguas minerales obtenidos de diversas fuentes (Álvarez, 1993; Gastil y Bertine, 1981; Secretaría de Programación y Presupuesto, 1981; Vidal et al., 1978; James, 1972).

Se obtuvieron datos de temperatura del agua de 62 pozos, pero solamente 45 de ellos 
anion (chloride, bicarbonate, carbonate and sulfate).

Due to the lack of homogeneity in the data, only 26 samples that contained the $\mathrm{SiO}_{2}$ information required by the silica geothermometry method, were used.

The geotemperatures calculated were obtained using the method proposed by Truesdell (1976). The silica geothermometer technique presents several restrictions in its application that have been discussed by White (1970) and Fournier et al. (1974), however, this methodology has been a useful tool to estimate reservoir temperatures (Buntebarth, 1994; Nicholson, 1993; Hilficker et al., 1980; Fournier, 1977). The following considerations are given to validate the technique used:

- The silica geothermometer method is based on the dependency of quartz solubility on temperature in the water as stated by Fournier and Rowe (1966).

- According to the study carried out by Vidal et al. (1978), there is an adequate supply of $\mathrm{SiO}_{2}$ and this enrichment can be safely attributed to high temperature of the water-rock interactions at depth, which are in equilibrium in respect to quartz. Also, Vidal et al. (1978) found that the residence time of water in several springs (50 to 60 years) is long enough to assume the existence of a fluid equilibrium in the mineral reservoir.

In order to obtain a representative mean regional value that could not be affected by possible anomalies and, thus be considered as normal (Swamberg and Morgan, 1980), this study did not consider the samples with surface temperature values higher than the average plus a standard deviation, given that these can be considered as thermal anomalies.

To facilitate the interpretation of the local heat flow results $(q)$ of this study, a qualitative scale was defined, taking the mean heat flow contaban con la información requerida para ser usados en un diagrama ternario de $\mathrm{Cl}-\left(\mathrm{HCO}_{3}+\right.$ $\mathrm{CO}_{3}$ )- $\mathrm{SO}_{4}$, como lo propuso Nicholson (1993), para clasificar el tipo de agua de la fuente hidrotermal, con base en el anión dominante (cloruro, bicarbonato, carbonato y sulfato).

Debido a la falta de homogeneidad de los datos, solamente se utilizaron las 26 muestras que contenían la información de $\mathrm{SiO}_{2}$ requerida por el método de geotermometría de sílice.

Las geotemperaturas calculadas fueron obtenidas utilizando el método propuesto por Truesdell (1976). La técnica de geotermometría de sílice presenta varias restricciones en su aplicación que fueron discutidas por White (1970) y Fournier et al. (1974), sin embargo, esta metodología ha demostrado ser una herramienta útil para estimar las temperaturas de los reservorios (Buntebarth, 1994; Nicholson, 1993; Hilficker et al., 1980; Fournier, 1977). Para validar la técnica utilizada se toman en cuenta las siguientes consideraciones:

- El método de geotermometría de sílice se basa en que la solubilidad del cuarzo es dependiente de la temperatura del agua como lo establecieron Fournier y Rowe (1966).

- De acuerdo al estudio llevado a cabo por Vidal et al. (1978), existe un suministro suficiente de $\mathrm{SiO}_{2}$ y este enriquecimiento puede ser seguramente atribuido a la alta temperatura de las interacciones agua-roca a profundidad, las cuales se encuentran en equilibrio con respecto al cuarzo. También, Vidal et al. (1978), encontraron que el tiempo de residencia en algunos manantiales (50 a 60 años) es lo suficientemente largo para asumir la existencia de un equilibrio de fluidos en el yacimiento mineral.

Para obtener un valor promedio representativo de la región que no pudiera ser afectado por posibles anomalías y, por ende, considerarse como normal (Swamberg y Morgan, 
value as a reference in the following manner: for $q<87.76 \mathrm{~mW} \mathrm{~m}^{-2}$, a low heat flow was considered; for $87.76 \leq q \leq 123.33 \mathrm{~mW} \mathrm{~m}^{-2}$, it was considered a medium heat flow; and for $q>123.33 \mathrm{~mW} \mathrm{~m}^{-2}$, a high heat flow was considered.

Swamberg and Morgan (1980) showed that the heat flow can be determined by the calculation of geotemperatures using the silica geothermometer, based on the following empirical equation:

$$
\mathrm{TSiO}_{2}=m q+\mathrm{T}_{\mathrm{o}}
$$

where $\mathrm{TSiO}_{2}$ is the silica geotemperature $\left({ }^{\circ} \mathrm{C}\right)$ of the sample, $m=0.670^{\circ} \mathrm{C} \mathrm{m}^{2} \mathrm{~mW}^{-1}, \mathrm{~T}_{\mathrm{o}}$ is the surface mean annual temperature $\left({ }^{\circ} \mathrm{C}\right)$ and $q$ is the heat flow expressed in $\mathrm{mW} \mathrm{m}^{-2}$. Based on equation (1) and taking $16.3^{\circ} \mathrm{C}$ as the mean annual temperature value $\left(\mathrm{T}_{\mathrm{o}}\right)$ for the region, according to the Instituto Nacional de Estadistica, Geografía e Informática (INEGI, 1996), the heat flow values for 26 wells were calculated. Due to the lack of conventional estimates of the heat flow in the area through direct temperature measurements with depth and thermal conductivity of rocks, and according to GarcíaEstrada (1989), a proportionality constant value of $m$ equal to $0.670^{\circ} \mathrm{C} \mathrm{m}^{2} \mathrm{~mW}^{-1}$ was used.

\section{RESULTS}

The following results can be observed from figure 2:

- Chloride was the dominant anion in $85 \%$ of the wells and springs studied, followed by the bicarbonate ion (15\%).

- The concentration of the water samples, close to the chloride vertex, and the dispersion observed to the middle of the graph indicate that dilution and mixing processes are occurring in the area, among different
1980), en este estudio no se consideraron muestras con valores de temperatura superficial más altos que el promedio más una desviación estándar, dado que éstas pueden considerarse anomalías térmicas.

Para facilitar la interpretación de los resultados de flujo de calor locales $(q)$ de este estudio, se definió una escala cualitativa, tomando el valor de flujo de calor promedio como una referencia, considerando: flujo de calor bajo cuando $q<87.76 \mathrm{~mW} \mathrm{~m}^{-2}$; flujo de calor medio cuando $87.76 \leq q \leq 123.33 \mathrm{~mW} \mathrm{~m}^{-2}$; y flujo de calor alto cuando $q>123.33 \mathrm{~mW} \mathrm{~m}^{-2}$.

Swamberg y Morgan (1980) mostraron que el flujo de calor puede ser determinado por el cálculo de geotemperaturas utilizando la geotermometría de sílice, basándose en la siguiente ecuación empírica:

$$
\mathrm{TSiO}_{2}=m q+\mathrm{T}_{\mathrm{o}}
$$

donde $\mathrm{TSiO}_{2}$ es la geotemperatura de sílice $\left({ }^{\circ} \mathrm{C}\right)$ de la muestra, $m=0.670^{\circ} \mathrm{C} \mathrm{m}^{2} \mathrm{~mW}^{-1}, \mathrm{~T}_{\mathrm{o}}$ es el promedio anual de la temperatura superficial $\left({ }^{\circ} \mathrm{C}\right)$ y $q$ es el flujo de calor expresado en

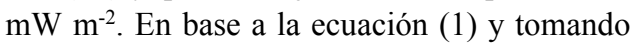
$16.3^{\circ} \mathrm{C}$ como el valor medio anual de la temperatura $\left(\mathrm{T}_{\mathrm{o}}\right)$ para la región, de acuerdo al Instituto Nacional de Estadística, Geografía e Informática (INEGI, 1996), se calcularon los valores de flujo de calor para los 26 pozos. Debido a la falta de estimaciones convencionales del flujo de calor en el área mediante mediciones directas de la temperatura a profundidad y de la conductividad térmica de las rocas, y de acuerdo a García-Estrada (1989), se utilizó un valor de la constante de proporcionalidad $(\mathrm{m})$ igual a $0.670^{\circ} \mathrm{C} \mathrm{m}^{2} \mathrm{~mW}^{-1}$.

\section{RESULTADOS}

En la figura 2 se pueden observar los siguientes resultados: 


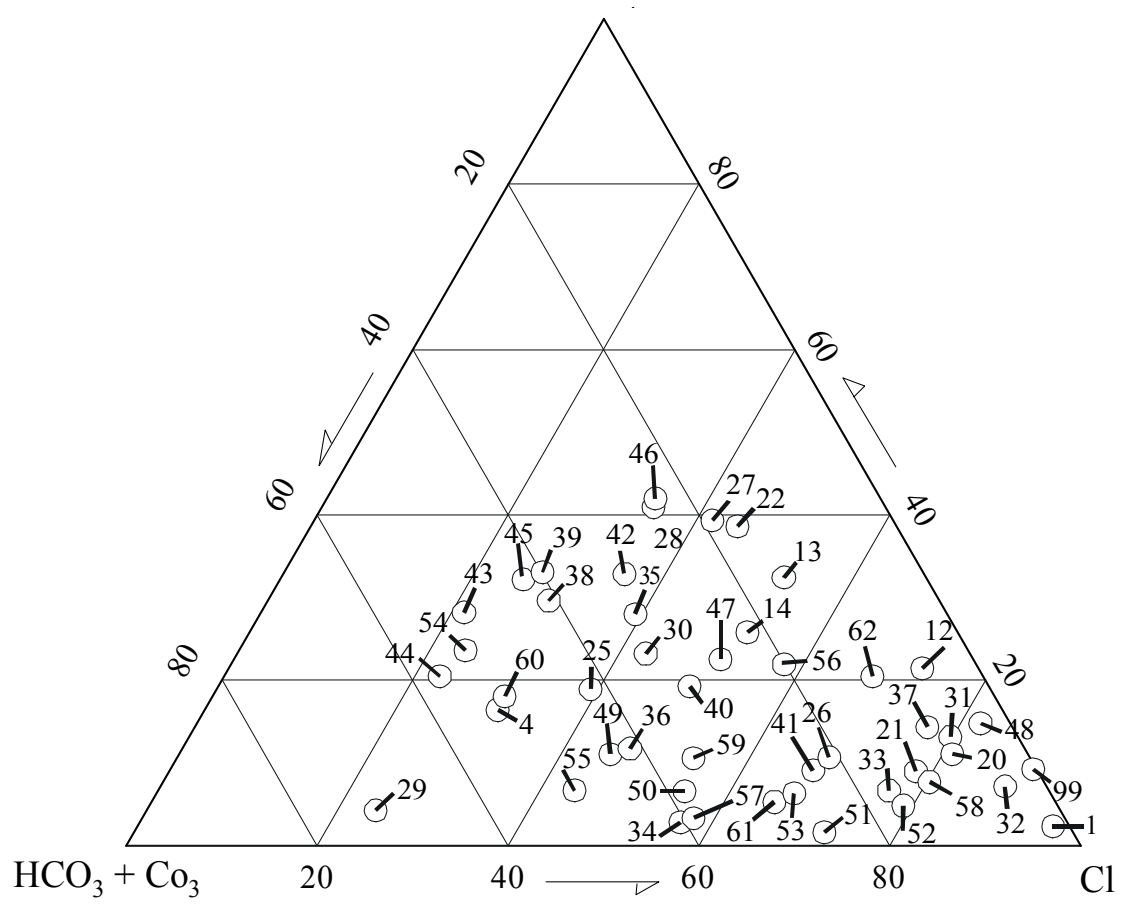

Figure 2. Classification of the water samples.

Figura 2. Clasificación de las muestras de agua.

types of water. According to Nicholson (1993), the water was classified as dilute chloride-bicarbonate water, and this type of fluid is generally found in low-temperature spring systems.

Figure 3 shows that the temperature frequencies at the surface, for the 62 samples in the study area, indicate that $61 \%$ of the data is within the temperature range from $10^{\circ} \mathrm{C}$ to $25^{\circ} \mathrm{C} ; 34 \%$ are distributed between $25^{\circ} \mathrm{C}$ and $65^{\circ} \mathrm{C}$; and $5 \%$ have temperatures higher than $65^{\circ} \mathrm{C}$. The mean surface water temperature was $30.21^{\circ} \mathrm{C} \pm 20.47^{\circ} \mathrm{C}$. The high value of the standard deviation is due to extreme values in the original data, with a minimum of $10^{\circ} \mathrm{C}$ and a maximum of $108^{\circ} \mathrm{C}$. Based on the highest temperatures found at the surface and according to Barbier (1997) and Einarsson
- El cloruro fue el anión dominante en el $85 \%$ de los pozos y afloramientos estudiados, seguido por el ion bicarbonato (15\%).

- La concentración de las muestras de agua, cerca del vértice del cloruro, y la dispersión observada a la mitad de la gráfica indican que en el área están sucediendo procesos de dilución y mezcla entre los distintos tipos de agua. De acuerdo a Nicholson (1993), el agua fue clasificada como agua con cloruro y carbonato diluidos y este tipo de fluido generalmente se encuentra en sistemas de manantiales de baja temperatura.

La figura 3 muestra que, para las 62 muestras del área de estudio, las frecuencias de temperatura en superficie indican que el $61 \%$ de los datos se encuentran dentro del rango de los $10^{\circ} \mathrm{C}$ a $\operatorname{los} 25^{\circ} \mathrm{C}, 34 \%$ se distribuyen entre los 


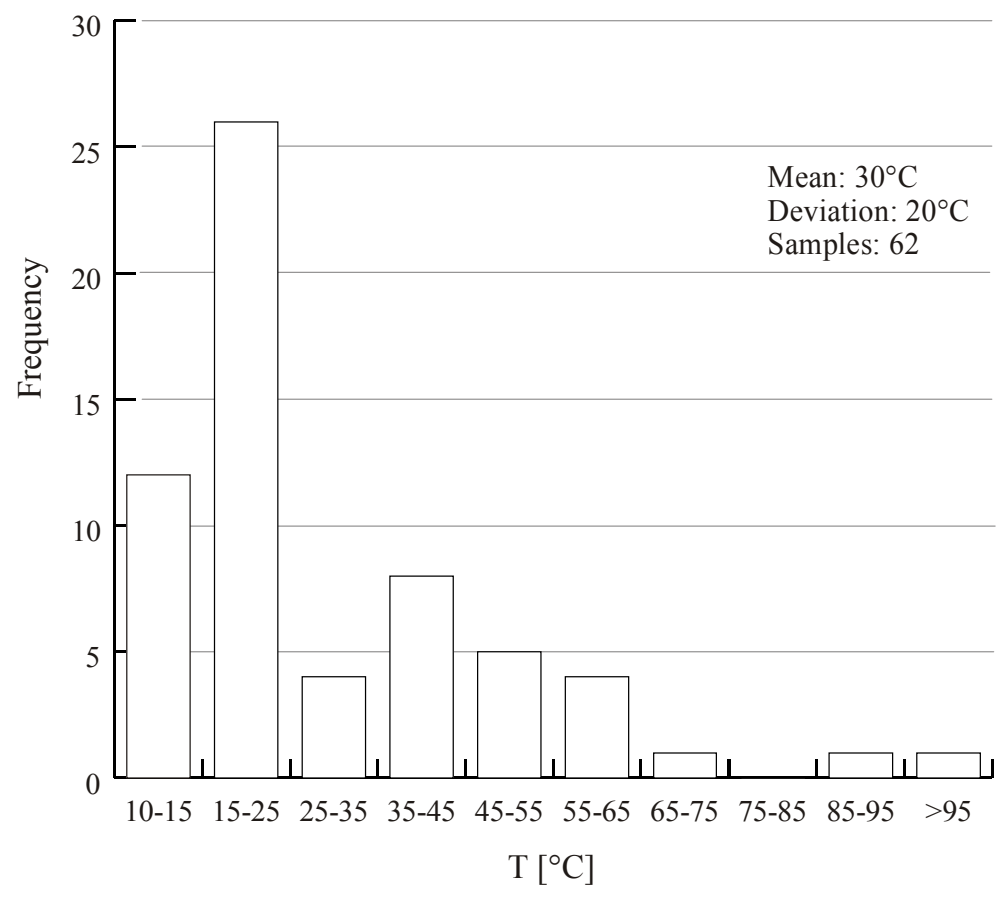

Figure 3. Temperature values of the samples for the Ensenada region.

Figura 3. Valores de temperatura de las muestras para la región de Ensenada.

(1978), the Ensenada region can be classified as a low temperature system with water temperatures, above the static level, that vary from $30^{\circ} \mathrm{C}$ to $108^{\circ} \mathrm{C}$.

An average geotemperature of $98^{\circ} \mathrm{C} \pm$ $23.83^{\circ} \mathrm{C}$ was obtained for the 16 representative samples of the study area, after omitting the 10 samples considered as having thermal anomalies (see table 1). Based upon the Swamberg and Morgan (1980) method, a regional mean value of $123.33 \pm 35.57 \mathrm{~mW} \mathrm{~m}^{-2}(2.95 \pm 0.85$ HFU) was obtained.

The results obtained for the heat flow values are shown in table 1 . The heat flow can be interpreted as anomalous when it is different to the mean regional value (García-Estrada, 1989). According to the qualitative scale of the $25^{\circ} \mathrm{C}$ y $\operatorname{los} 65^{\circ} \mathrm{C}$ y $5 \%$ presentan temperaturas superiores a $\operatorname{los} 65^{\circ} \mathrm{C}$. La temperatura superficial media fue de $30.21^{\circ} \mathrm{C} \pm 20.47^{\circ} \mathrm{C}$. El alto valor de la desviación estándar se debe a los valores extremos en los datos originales, con un mínimo de $10^{\circ} \mathrm{C}$ y un máximo de $108^{\circ} \mathrm{C}$. Basándose en las temperaturas superficiales más altas y de acuerdo a Barbier (1997) y Einarsson (1978), la región de Ensenada puede clasificarse como un sistema de baja temperatura con variaciones en la temperatura del agua, por encima del nivel estático, entre los $30^{\circ} \mathrm{C} \mathrm{y}$ $\operatorname{los} 108^{\circ} \mathrm{C}$.

Después de omitir las 10 muestras consideradas con anomalías (tabla 1 ), se obtuvo una geotemperatura media de $98^{\circ} \mathrm{C} \pm 23.83^{\circ} \mathrm{C}$ para las 16 muestras representativas del área de estudio (ver tabla 1). Con base en el método de 
Table 1. Silica-heat flow data.

Tabla 1. Datos de flujo de calor-sílice.

\begin{tabular}{|c|c|c|c|c|}
\hline Sample & $\begin{array}{c}\text { Flowing water } \\
\mathrm{T}^{\circ} \mathrm{C}\end{array}$ & $\begin{array}{l}\mathrm{SiO}_{2} \\
\mathrm{mg} / 1\end{array}$ & $\begin{array}{c}\text { Geo } \mathrm{T}^{\circ} \mathrm{C} \\
\text { silica }\end{array}$ & $\begin{array}{l}\text { Heat flow } \\
\mathrm{mW} \mathrm{m}^{-2}\end{array}$ \\
\hline 1 (an) & 108 & $156(\mathrm{e})$ & 163.46 & 219.63 \\
\hline 2 (an) & 95 & $105(\mathrm{e})$ & 139.88 & 184.44 \\
\hline 3 (an) & 70 & 87 (a) & 129.55 & 169.03 \\
\hline 4 (an) & 64 & 78 (c) & 123.78 & 160.42 \\
\hline 5 (an) & 60 & 90 (c) & 131.37 & 171.75 \\
\hline 6 (an) & 60 & 98 (a) & 136.03 & 178.70 \\
\hline 7 (an) & 57 & 42 (a) & 93.99 & 115.95 \\
\hline 8 (an) & 55 & 42 (a) & 93.99 & 115.95 \\
\hline 9 (an) & 55 & 98 (a) & 136.03 & 178.70 \\
\hline 10 (an) & 50 & 40 (a) & 91.83 & 112.73 \\
\hline $11(\mathrm{n})$ & 49 & 52 (a) & 103.75 & 130.52 \\
\hline $12(\mathrm{n})$ & 48 & 98 (c) & 136.03 & 178.70 \\
\hline $13(n)$ & 44 & 48 (b) & 100.03 & 124.97 \\
\hline $14(\mathrm{n})$ & 44 & 47 (c) & 99.07 & 123.53 \\
\hline $15(\mathrm{n})$ & 43 & 38 (b) & 89.59 & 109.38 \\
\hline $16(\mathrm{n})$ & 42 & 36 (a) & 87.25 & 105.90 \\
\hline $17(\mathrm{n})$ & 40 & 32 (a) & 82.27 & 98.46 \\
\hline $18(\mathrm{n})$ & 40 & 32 (a) & 82.27 & 98.46 \\
\hline $19(\mathrm{n})$ & 40 & 94 (a) & 133.73 & 175.28 \\
\hline $21(\mathrm{n})$ & 33 & 86 (c) & 128.93 & 168.10 \\
\hline $22(n)$ & 32 & 92 (c) & 132.56 & 173.53 \\
\hline $23(n)$ & 29 & 12 (a) & 45.57 & 43.69 \\
\hline $24(\mathrm{n})$ & 27 & 27 (a) & 75.32 & 88.09 \\
\hline $25(\mathrm{n})$ & 22 & 40 (c) & 91.83 & 112.73 \\
\hline $31(\mathrm{n})$ & 20 & $36(\mathrm{e})$ & 87.25 & 105.90 \\
\hline $37(n)$ & 18 & 47 (c) & 99.07 & 123.53 \\
\hline
\end{tabular}

(a) Álvarez (1993); (b) James (1972); (c) Gastil y Bertine (1981); (e) Vidal (1978).

(an) anomalous temperature; (n) normal temperature. 
heat flow values, there are several areas that presented thermal anomalies which are shown in figures 4. Furthermore, these figures also show the classification and location of the areas mentioned above.

Four areas were identified, with at least one high value. Also, a positive correlation was found between the heat flow and the surface water temperature $(r=0.74)$. Consequently, we expected to find high heat flow values according to the scale used. This was the case for zone I, in which all the thermal springs showed heat flow values higher than $123.33 \mathrm{~mW} \mathrm{~m}^{-2}$. The sample 5 was the only one in the zone II that fulfilled this assumption, while samples 7, 8 and 10 were identified as thermal springs with a medium heat flow value. Sample 12 (zone III) and samples 21 and 22 (zone IV) presented high heat flow values, even though they were not identified as thermal springs.

\section{DISCUSSION}

The enrichment of $\mathrm{SiO}_{2}$ in the water samples, as mentioned by Vidal and Vidal (1981), can be accounted for by two mechanisms: (1) hydrothermal water evolution within marine strata or deposits; and (2) hot water-igneous rock interactions at elevated temperatures $\left(\sim 200^{\circ} \mathrm{C}\right)$ and pressures. The first mechanism is explained by the presence of the Alisitos and Rosario marine sedimentary formations of Cretaceous age within the Ensenada-Punta Banda region quadrangle. The second mechanism is explained by the product of the reaction of seawater with basalt at high pressures and temperatures in an acid $(\mathrm{pH}=5.2)$, reducing, sodium chloride solution, enriched in $\mathrm{Ca}^{2+}$, $\mathrm{SiO}_{2}, \mathrm{H}_{2} \mathrm{~S}$, and trace metals depleted in $\mathrm{Mg}^{2}$ and $\mathrm{SO}_{4}{ }^{-2}$; chemical characteristics found by Vidal and Vidal (1981) in the Punta Banda sub-
Swamberg y Morgan (1980), se obtuvo un valor regional medio de $123.33 \pm 35.57 \mathrm{~mW} \mathrm{~m}^{-2}$ (2.95 $\pm 0.85 \mathrm{HFU})$.

En la tabla 1 se muestran los resultados obtenidos de los valores de flujo de calor. Éste puede ser interpretado como anómalo cuando es diferente al del valor regional medio (García-Estrada, 1989). De acuerdo a la escala cualitativa de los valores de flujo de calor, existen algunas áreas en donde se presentan anomalías térmicas las cuales son presentadas en las figuras 4. Además, estas figuras muestran también la clasificación y localización de las áreas anteriormente mencionadas.

Se identificaron cuatro áreas con, al menos, un valor alto. También se encontró una correlación positiva entre flujo de calor y temperatura superficial del agua $(r=0.74)$. Consecuentemente se esperaba encontrar valores de flujo de calor altos, de acuerdo a la escala utilizada. Este fue el caso de la zona I, en la que todos los afloramientos termales mostraron valores de flujo de calor mayores a $123.33 \mathrm{~mW} \mathrm{~m}^{-2}$. La muestra 5, en la zona II, fue la única que también satisfizo esta condición, mientras que las muestras 7,8 y 10 se identificaron como afloramientos termales con un valor medio de flujo de calor. La muestra 12 (zona III) y las muestras 21 y 22 (zona IV) presentaron valores de flujo de calor altos, aunque estos no habían sido identificadas como afloramientos termales.

\section{DISCUSIÓN}

El enriquecimiento con $\mathrm{SiO}_{2}$ en las muestras de agua, como lo mencionaron Vidal y Vidal (1981), puede deberse a dos mecanismos: (1) la evolución del agua hidrotermal en depósitos o estratos marinos; y (2) las interacciones entre el agua caliente y las rocas ígneas a temperaturas elevadas $\left(200^{\circ} \mathrm{C}\right)$ y alta presión. 
marine hot spring solutions.

The establishment of an equilibrium in the reservoir depends on the following factors: the kinetics reaction, the reservoir temperature, the wall reactivity of the rocks, the concentrations of an indicative element in the water and the residence time of water in the reservoir at a certain temperature (Fournier, 1977). Under certain conditions, the reservoir equilibrium could be obtained by means of certain reactions that may occur. Also, whether or not the water reaches a re-equilibrium, depends on: the flow rate, the ascending route, the type and reactivity of the rock where it goes through, the initial temperature of the reservoir and the kinetics of the reactions that could occur.

A total or partial equilibrium could be reached if we assume that there are wells and springs that occur as a mixing of warm water found at depth, mixed with cold water from the surface. If a chemical equilibrium occurred after the mixing, the geothermometer will indicate the temperature of the resulting mixed fluid, which is not the one of the warm water that is at depth. This is why Fournier (1977) and Buntebarth (1994) assumed that the estimation of the temperature could be less than the actual one in the reservoir. If an equilibrium of the fluid-mineral cannot be reached, according to that mentioned by Hilkfiker et al., (1980), the results obtained could yield nonconfident resulting data. This could be the case if most of the geotemperatures calculated were very high (between $200^{\circ} \mathrm{C}$ to $300^{\circ} \mathrm{C}$ ), or on the contrary, temperatures under $10^{\circ} \mathrm{C}$ or negative values were present, in which case, the best choice would be to eliminate the extreme values.

Swamberg and Morgan (1980) have shown that the methodology used in this study has proved to be successful when using a small number of samples. García-Estrada (1989) also
El primer mecanismo se explica por la presencia de las formaciones de sedimentos marinos de Alisitos y Rosario localizadas en la zona de Ensenada-Punta Banda, y que datan del Cretácico. El segundo mecanismo se explica por el producto de la interacción del agua de mar con basaltos a altas presión y temperatura en una solución de cloruro de sodio, ácida $(\mathrm{pH}=5.2) \mathrm{y}$ reductora, enriquecida con $\mathrm{Ca}^{2+}, \mathrm{SiO}_{2}, \mathrm{H}_{2} \mathrm{~S}$ y metales traza reducidos en $\mathrm{Mg}^{2}$ y $\mathrm{SO}_{4}{ }^{-2}$. Estas características químicas fueron encontradas por Vidal y Vidal (1981) en las soluciones de los afloramientos termales submarinos de Punta Banda.

El establecimiento de un equilibrio en el reservorio depende de los siguientes factores: La reacción cinética, la temperatura del reservorio, la reactividad de las paredes de roca, las concentraciones de un elemento indicador en el agua y el tiempo de residencia del agua en el reservorio a una temperatura determinada (Fournier, 1977). Bajo ciertas condiciones, el equilibrio del reservorio se puede lograr una vez que ocurran ciertas reacciones posibles. También el hecho de que el agua alcance o no un reequilibrio depende de la tasa de flujo, la ruta de ascenso, el tipo y reactividad de la roca que atraviesa, la temperatura inicial del reservorio y la cinética de las reacciones que pueden ocurrir.

Se puede alcanzar un equilibrio total o parcial si se asume que existen pozos y afloramientos que se presentan con una mezcla de agua caliente del fondo y agua fría de la superficie. Si ocurre un equilibrio químico después de la mezcla, la geotermometría indicará la temperatura del fluido ya mezclado, que no es la misma que la del agua caliente profunda. Esta es la razón por la que Fournier (1977) y Buntebarth (1994) asumieron que la estimación de la temperatura puede ser menor que la que 

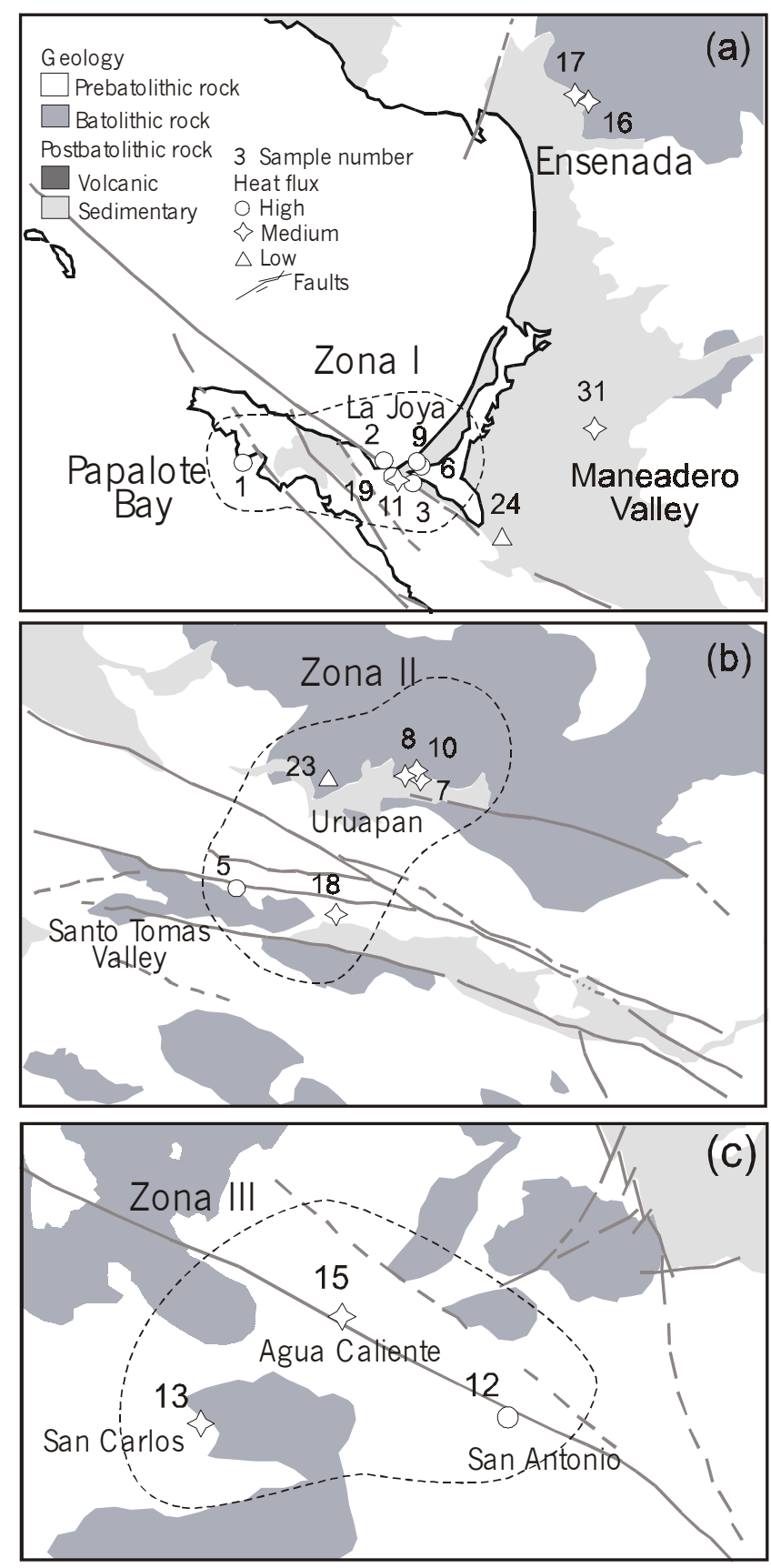

Figure 4.

Figura 4. 


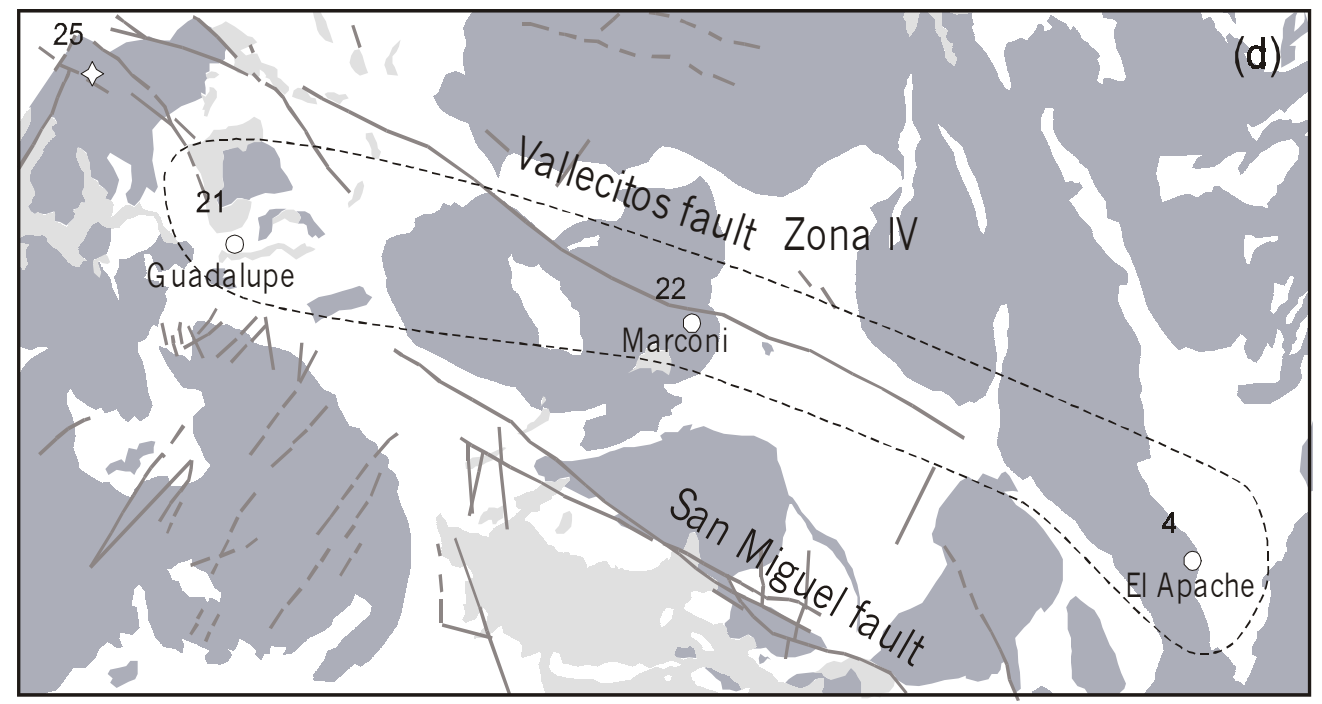

Figure 4. Hydrothermal activity zones and sampling sites. (a) Zone I, (b) Zone II, (c) Zone III, (d) Zone IV. Figura 4. Zonas de actividad hidrotermal y sitios de muestreo. (a) Zona I, (b) Zona II, (c) Zona III, (d) Zona IV.

found this method useful and suitable even when the number of samples is few. However, the restriction of using standard deviation $\left(<25^{\circ} \mathrm{C}\right)$ exists, as well as the need of a good coverage of the area. The analyzed samples fulfilled these restrictions, therefore, we can assume that the mean regional value calculated is representative of the area.

The results allowed us to make the following assumptions:

1) The proposed definition of anomalous temperature discriminates, in a radical way, $19 \%$ of the samples that could be classified as thermal springs. These presented moderate temperatures ranging from $30^{\circ} \mathrm{C}$ to $49^{\circ} \mathrm{C}$, v.gr. samples 12 and 22.

2) According to Barbier (1997), the mean heat flow value in the region is high, $123.33 \pm$ $35.57 \mathrm{~mW} \mathrm{~m}^{-2}$ (2.95 \pm 0.85 HFU). This high value is the result of the heat flow calculated realmente se da en el reservorio. De acuerdo a lo mencionado por Hilfiker et al. (1980), los resultados obtenidos no pueden brindar datos confiables si no se alcanza un equilibrio entre el fluido y los minerales. Este sería el caso, si la mayoría de las geotemperaturas calculadas fueran muy altas (entre $200^{\circ} \mathrm{C} \mathrm{y} 300^{\circ} \mathrm{C}$ ) o, por el contrario, si éstas presentaran valores menores a $10^{\circ} \mathrm{C}$ o negativos, en cuyo caso, la mejor opción sería la de eliminar los valores extremos.

Swamberg y Morgan (1980) han mostrado que la metodología utilizada en este estudio ha probado ser exitosa cuando se utilizan una cantidad de muestras pequeña. García-Estrada (1989) también encontró este método útil y factible aún cuando el número de muestras es bajo. Sin embargo, existe la restricción de utilizar la desviación estándar $\left(<25^{\circ} \mathrm{C}\right)$, así como la necesidad de una buena cobertura del área de 
with the average of the 16 representative well water samples with normal temperatures. The extreme $\mathrm{T}^{\circ} \mathrm{C}$ values found in the data could overestimate the definition of normal well-head water temperatures; thus, the high flow value could be overestimated. Also, in the samples with surface water temperatures considered as normal or those that presented lower temperatures, the silica species such as chalcedony, cristobalite or amorphous silica, might be controlling the dissolved silica, as stated by Fournier and Rowe (1966).

3) Most of the wells and springs that presented a surface temperature value higher than $30^{\circ} \mathrm{C}$, showed a clear trend in respect to the main fault systems of the region, leading to the assumption that they are related to the thermal activity found in the area. This assumption is in agreement with Vidal et al. (1982). We conclude that the hydrothermal system of the Punta Banda area is the product of deep circulation along the Punta Banda Fault system, rather than tectonic or magmatic activity.

\section{CONCLUSIONS}

The Ensenada, Baja California, region is classified as a low-temperature system with water temperatures, above the static level, that vary from $30^{\circ} \mathrm{C}$ to $108^{\circ} \mathrm{C}$.

The water-type identified in the study area is that of dilute chloride-bicarbonate water; the dominant anion in $84.7 \%$ of the wells and springs was the chloride ion.

Temperatures above the water static level $\left(>60^{\circ} \mathrm{C}\right)$ were identified at 10 sites. These were classified as anomalies that indicate a possible thermal activity associated with the Agua Blanca fault, in the areas of Papalote Bay (at La Bufadora), La Joya and Ejido Uruapan.

The regional mean value of the heat flow that was calculated for the study area is $123.33 \pm 35.57 \mathrm{~mW} \mathrm{~m}^{-2}(2.95 \pm 0.85 \mathrm{HFU})$. estudio. Las muestras analizadas cumplieron con estas restricciones, por lo tanto, podemos asumir que el valor regional promedio calculado es representativo del área.

Los resultados nos permitieron hacer las siguientes suposiciones:

1) La definición propuesta de temperatura anómala discrimina de manera radical $19 \%$ de las muestras que pudieran ser clasificadas como afloramientos termales. Estos presentaron temperaturas moderadas que variaron entre $\operatorname{los} 30^{\circ} \mathrm{C}$ y $\operatorname{los} 49^{\circ} \mathrm{C}$, v.g. muestras 12 y 22 .

2) De acuerdo a Barbier (1997), el valor medio de flujo de calor en la región es alto, $123.33 \pm 35.57 \mathrm{~mW} \mathrm{~m}^{-2}(2.95 \pm 0.85$ HFU $)$. Este alto valor es el resultado del flujo de calor calculado con los promedios de las 16 muestras de agua de pozos representativos con temperaturas normales. Los valores extremos de temperatura encontrados en los datos podrían sobreestimar la definición de la temperatura normal del agua de los pozos, por lo que el valor alto de flujo puede estar sobreestimado. De igual forma, en las muestras con temperaturas superficiales del agua consideradas como normales, o en aquellas que presentaron temperaturas bajas, las especies de sílice como la calcedonita, crisobalita o sílice amorfo pueden estar controlando la disolución del sílice como lo mencionaron Fournier y Rowe (1966).

3) La mayoría de los pozos y afloramientos que presentaron un valor de temperatura superficial mayor a $30^{\circ} \mathrm{C}$, mostraron una tendencia clara con relación a los principales sistemas de fallas de la región, lo que hace suponer que se encuentran relacionados con la actividad termal encontrada en el área. Ésta idea va de acuerdo con lo propuesto por Vidal et al. (1982). Concluimos que el sistema hidrotermal del área de Punta Banda es producto de una circulación profunda a lo largo del sistema de la Falla de Punta Banda, más que de la actividad tectónica o magmática. 
This value is considered high because it is 1.5 times higher than the average value of the Earth.

Four areas with high hydrothermal activity were identified:

Zone I. Papalote Bay and La Joya, located in the Punta Banda peninsula (fig. 4a). This zone was characterized by having the highest hydrothermal activity in the area, with anomalous surface water temperature values $\left(55^{\circ}\right.$ to $\left.108^{\circ} \mathrm{C}\right)$, very high heat flow values $\left(>123.33 \mathrm{~mW} \mathrm{~m}^{-2}\right.$ ), and a positive correlation between both variables.

Zone II. Hydrothermal springs located in the Ejido Uruapan and Santo Tomás Valley (fig. 4b). Temperatures range from $40^{\circ} \mathrm{C}$ to $60^{\circ} \mathrm{C}$ and a medium heat flow value is present.

Zone III. This area includes the springs of San Antonio, San Carlos and Agua Caliente (fig. 4c). The discharge temperature ranged from $43^{\circ} \mathrm{C}$ to $48^{\circ} \mathrm{C}$. The heat flow value calculated was medium.

Zone IV. The springs of Marconni, El Apache and Guadalupe are located in this area (fig. 4d). The discharge temperatures are 32, 64 and $33^{\circ} \mathrm{C}$, respectively. The heat flow value is considered high.

\section{REFERENCES}

Álvarez, R.J. (1993). Reconocimiento geotérmico en el área de Ensenada, Baja California. Residencia General de Cerro Prieto. Comisión Federal de Electricidad. Technical Report (Non published).

Atwater, T. (1970). Implications of plate tectonics for the Cenozoic tectonic evolution of Western North America. Geol. Soc. America Bull., 18: 3513-3536.

Barbier, E. (1997). Nature and technology of geothermal energy: a review. Renewable and Sustainable Energy Reviews, 1(1/2): 1-69.

Buntebarth, G. (1994). Geotermia. Introducción a los aspectos aplicados y teóricos de la conducción del calor en la Tierra. Grafos Editores S.A. de C.V. Primera edición. México, D.F. 183 pp.

Einarsson, S.S. (1978). Opportunities for direct use

\section{CONCLUSIONES}

La región de Ensenada, Baja California se clasifica como un sistema de baja temperatura, con valores de temperatura del agua, por arriba del nivel estático, que varían desde $\operatorname{los} 30^{\circ} \mathrm{C}$ hasta los $108^{\circ} \mathrm{C}$.

El tipo de agua identificado en el área de estudio es el de agua con cloruro y bicarbonato diluidos. El anión dominante en el $84.7 \%$ de los pozos y manantiales fue el ion cloruro.

En 10 sitios se identificaron temperaturas por arriba del nivel estático del agua $\left(>60^{\circ} \mathrm{C}\right)$. Estas fueron clasificadas como anomalías que indican una posible actividad termal asociada con la falla de Agua Blanca en el área de Bahía Papalote (en La Bufadora), La Joya y el Ejido Uruapan.

El valor regional medio de flujo de calor calculado para el área de estudio fue de 123.33 $\pm 35.57 \mathrm{~mW} \mathrm{~m}^{-2}(2.95 \pm 0.85 \mathrm{HFU})$. Este es un valor considerado alto ya que es 1.5 veces mayor que el valor medio de la Tierra.

Se identificaron cuatro áreas con actividad hidrotermal:

Zona I. Bahía Papalote y La Joya, localizadas en la península de Punta Banda (fig. 4a). Esta zona se caracterizó por tener la actividad hidrotermal más alta del área, con valores anómalos de temperatura superficial del agua $\left(55^{\circ} \mathrm{C}\right.$ a $\left.108^{\circ} \mathrm{C}\right)$, valores muy altos de flujo de calor $\left(>123.33 \mathrm{~mW} \mathrm{~m}^{-2}\right.$ ) y una correlación positiva entre ambas variables.

Zona II. Afloramientos hidrotermales localizados en el Ejido Uruapan y el valle de Santo Tomás (fig. 4b). Las temperaturas varían de $40^{\circ} \mathrm{C}$ a $60^{\circ} \mathrm{C}$ y presentan un valor de flujo de calor medio.

Zona III. Esta área incluye los afloramientos de San Antonio, San Carlos y Agua Caliente (fig. 4c). La temperatura de descarga varía entre los $43^{\circ} \mathrm{C}$ y $\operatorname{los} 48^{\circ} \mathrm{C}$. El valor del flujo de calor calculado fue medio.

Zona IV. Los afloramientos de Marconni, El Apache y Guadalupe se localizan en esta 
of geoheat in Central America and other tropical countries. Geothermics, 6: 209-219.

Fournier, R.O. and Rowe, J.J. (1966). Estimation of underground temperatures from the silica content of water from hot springs and wet stream wells. Amer. J. Sci., 264: 685-697.

Fournier, R.O., White, D.E. and Truesdell, A.H. (1974). Geochemical indicators of subsurface temperature I, Basic assumptions. U.S. Geol. Survey J. Res. 2, 259-262.

Fournier, R.O. (1977). Chemical geothermometers and mixing models for geothermal systems. Geothermics, 5: 41-50.

García Estrada, G.H. (1989). Técnicas de medida del flujo térmico en continentes, métodos opcionales y su aplicación en México. Geotermia, Rev. Mex. Geoenergía. 5 (3): 375-410.

Gastil, R.G., Phillips, R.P. and Allison, E.C. (1975). Reconaissance geology of the state of Baja California. The Geological Society of America, Inc., Memoir 140. Boulder Colorado, USA. 170 pp.

Gastil, R.G., Morgan, G. and Krummenacher, D. (1979). The tectonic history of peninsular California and adjacent Mexico. Geol. Soc. Am. Bull., 90(9): 839-857.

Gastil, R.G. and Bertine, Kathe, K. (1981). Thermal water provinciality in southern and Baja California, U.S.A. and Mexico (abstr.): Geological Society of America. Abstracts with programs, 13(2), p. 57.

Hamza, V.M. and Muñóz, M. (1996). Heat flow map of South America. Geothermics 25(6): 599-646.

Hilfiker, K., Hanley, C., Hodge, D., Morgan, P., Maxwell, J. and Swamberg, C. (1980). Correlation of silica heat flow and temperature gradients, central and western New York. Geothermal Resources Council, Transactions Vol. 4: 209-212.

Instituto Nacional de Estadística, Geografía e Informática (1996). Ensenada. Estado de Baja California. Cuaderno Estadístico Municipal. Edición 1995. México.

James, A.L. (1972). Geochemical evaluation of temperature at depth for a proposed geothermal reservoir in the Ensenada-Punta Banda area, Baja California, Mexico. Undergraduate Research Report, SDSU, USA.

Nicholson, K. (1993). Geothermal fluids. Chemistry área (fig. 4d). Las temperaturas de descarga son $32,64 \mathrm{y} 33^{\circ} \mathrm{C}$, respectivamente. El valor del flujo de calor calculado se considera alto.

Traducido al español por Adrián R. López.

and exploration techniques. Springer-Verlag Berlin Heidelberg, Germany. 263 pp.

Quintanilla-Montoya, A.L. and Suárez-Vidal, F. (1992). Origin of a sedimentary sequence on the north island of Todos Santos, B.C. Mexico. Ciencias Marinas 18(1): 1-18pp.

Smith, D.L., Nuchels, E., Junes, R.L. and Cook, G.A. (1979). Distribution of heat flow and radioactive heat generation in northern Mexico, J. Geophys. Res. 84(85): 2371-2379.

Secretaría de Programación y Presupueso (1981). Carta Hidrológica de Aguas subterráneas. Escala 1:250000. Ensenada H11-2. S. P. P. México.

Swamberg, C.A. Morgan, (1980). The silica heat flow interpretation technique: Assumptions and aplications. Jour. Geophys. Res. 85(B12): 72067214.

Truesdell, A.H. (1976). Summary of section III, Geochemical techniques in exploration, Proc. 2nd U.N. Symp. on the Development and Use of Geothermal Resources, Vol. I, 53-79, Washington.

Vidal, V.M.V., Vidal, F.V., Isaacs, J.D. and Young, D.R. (1978). Coastal submarine hydrotermal activity off northern Baja California. J. Geophys. Res. 83 (B4): 1757-1774.

Vidal, V.M.V., and Vidal, F.V. (1981). Coastal submarine hydrothermal activity off northern Baja California. 2. Evolutionary History and Isotope Geochemistry. J. Geophys. Res. 86(B10): 9451-9468.

Vidal, F.V., Welhan, J. and Vidal, V.M.V. (1982). Stable isotopes of helium, nitrogen and carbon in acoastal submarine hydrothermal system. J. Volcanol. Geotherm. Res. 12: 101-110.

White, D.E. (1970). Geochemistry applied to the discovery, evaluation, and explotation of geothermal energy resources (Proc. U.N. Symp. on the Development and Utilization of Geothermal Resources, Pisa, 1970). Geothermics Sp. iss. 2,1: 58-80. 